\title{
ScienceAsia, Journal of the Science Society of Thailand, reflects maturation of science in Thailand
}

\author{
Yongyuth Yuthavong \\ National Science and Technology Development Agency, Thailand \\ e-mail: yongyuth@nstda.or.th
}

ABSTRACT: A brief review of the history of ScienceAsia is given by the first editor of the Journal of the Science Society of Thailand/ScienceAsia.

The early years of the Science Society of Thailand saw gradual development from a gathering of a handful of scientists, mostly in Chulalongkorn University and government departments, to a broad professional community with ambitions further than those of a social club. As the Society was entering its third decade, in the 1970s, it was in many ways like a young person aspiring to fulfill promises of a great career. Science was flourishing in a new Faculty of Science at Mahidol University, or University of Medical Sciences as it was then called, with new staff members fresh from the best universities all over the world and the first substantial graduate degree programmes. New universities were started in major provinces like Chiang Mai, Songkhla, and Khon Kaen, while others were transformed from technical and teacher training colleges. In the background, the economy was booming as the Vietnam War rolled into its final years, and Thailand was going through its lessons in student-inspired democracy.

It was in this atmosphere that I was approached by Dr Kamchad Mongkolkul, then Editor of Science magazine, then the only publication of the Society which publishes general articles and news on science in Thai. He foresaw the need for a professional science journal, which would be the venue for publishing research of Thai scientists, and together with Dr Stitya Sirisinha and other people, convinced me to take the job of the editor of this newly planned journal. Named Journal of the Science Society of Thailand, it was to be the first journal from Thailand publishing works on natural and allied sciences, in addition to a few professional journals in medicine and agriculture already in existence. I took on this job for the first ten years of the journal (19751984), and another two years (1999-2000) when the journal adopted the name ScienceAsia, in order to reflect its widening scope.

My first task was to form the policy of the journal with the people who initiated the idea, to be in line with the broader policy of the Science Society of Thailand. Broadly, this policy was to further the goal of deepening the contribution of science from Thailand to the world as well as highlighting international research results, especially those which impact Thailand and Asia in general. Then as well as now, as a member of the Executive Committee of the Society, the editor reported to the Committee and undertook the role which ensured that the Society plays a significant part in science research communication among the scientists of Thailand and in the world. A core budget was allocated for the publication and running of the journal, but had to be supplemented by other sources. The Ministry of University Affairs gave the journal the extra support needed in those early years. An editorial board was formed, comprising active scientists from many institutions to help the editor deal with various issues, ranging from coverage of scientific subjects, types of articles, inviting articles from noted scientists, reviewing and suggesting reviewers for submitted articles, to format of the journal. The editorial board met in persons for a few times, after which the work was done mainly by conversation and correspondence.

The main features of the journal were that it would be published quarterly, in English, with articles including invited reviews, full research articles and research reports. Editorials and book reviews were also published in early issues. Looking back, it is notable that many reviews and research articles are not only of high quality, but reflected the current issues and the interest of Thai scientists and 

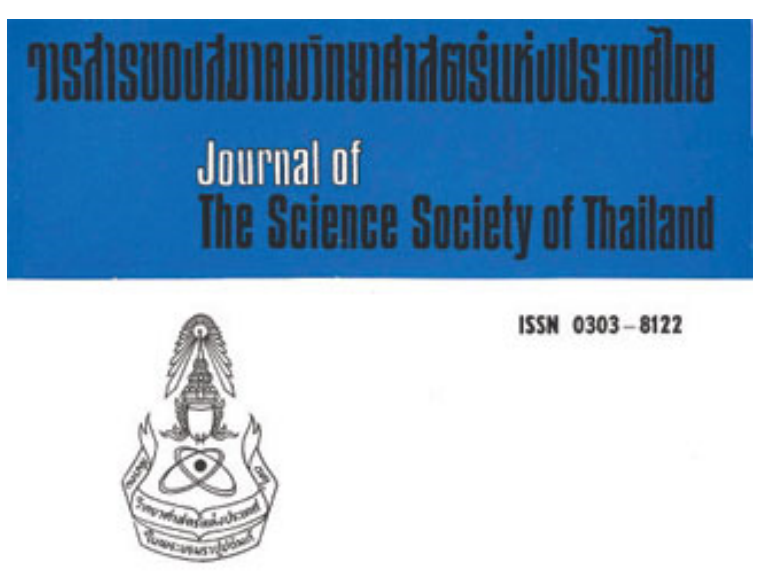

ISSN 0303-8122

\section{J. Sci. Soc. Thailand \\ Vol. 1 No. 1 \\ June 1975}

Fig. 1 The cover of the first issue of Journal of the Science Society of Thailand, $(1,1,1975)$

world collaborators at the time. The articles of the first issue (cover in Fig. 1), for example, include reviews on sperm capacitation by Colin Austin ${ }^{1}$, a key collaborator of Robert Edwards who later received the Nobel Prize for his work in reproductive biology, and on science centres by R.S. Bhatal ${ }^{2}$ who later became the Foundation Director of Singapore Science Centre. Research articles included one by H. Lehmann and A. Lang on abnormal haemoglobin and thalassaemia ${ }^{3}$, recognizing the contributions of Thai researchers in this important area, and one by Jisnuson Svasti and Sumalee Viriyachai on human lactate dehydrogenases ${ }^{4}$, reflecting the interest of the research community then on reproductive biology. Later issues, with improved formatting (Fig. 2) featured wide-ranging articles such as those by M.J. Moravcsik and Sanga Sabhasri on science development and science policy ${ }^{5,6}$, foreshadowing efforts to improve its status, and one on fodder fractionation and leaf protein by N.W. Pirie ${ }^{7}$, a great biochemist who later turned his interest on feeding the world. Sood Sangvichien, a noted anthropologist and medical teacher, contributed articles on posture and skull features of prehistoric humans ${ }^{8}$. Issues

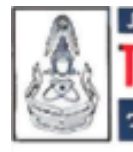

JOURNAL OF THE SCIENCE SOCIETY OF THAILAND

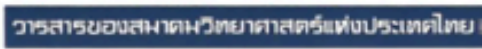

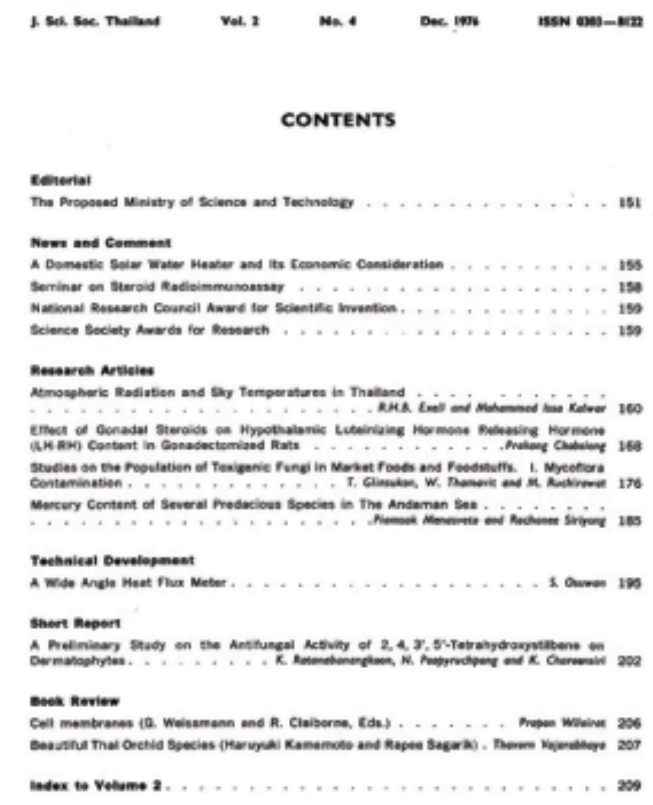

Fig. 2 The re-designed cover of the journal, which was in use until 1999.

discussed in the editorials, many of which have now been favourably resolved, included the need for a Ministry of Science and Technology, strategy for building up research manpower in Thailand, choice of appropriate technology, private sector research and development, and establishment of the National Centre for Genetic Engineering and Biotechnology.

From the start, efforts were made to have Journal of the Science Society of Thailand listed in Current Contents and covered by Science Citation Index. This was successful after many attempts, with listing in Agriculture, Biology and Environmental Sciences Section of Current Contents, although it was discontinued later, probably due to delays in publication in the early 1990s. The journal is now covered by various international databases, such as PubMed, CAPlus, and Thomson Master List of Journals. The citation record in 1979 was 0.26, with ranking of 32 among 56 covered science journals in the world. This record was used as a rallying point for Thai and international scientists to consider reading and publishing more in the journal (Fig. 3).

After the first period of my editorship ended in 1984, we had five more editors: Jisnuson 


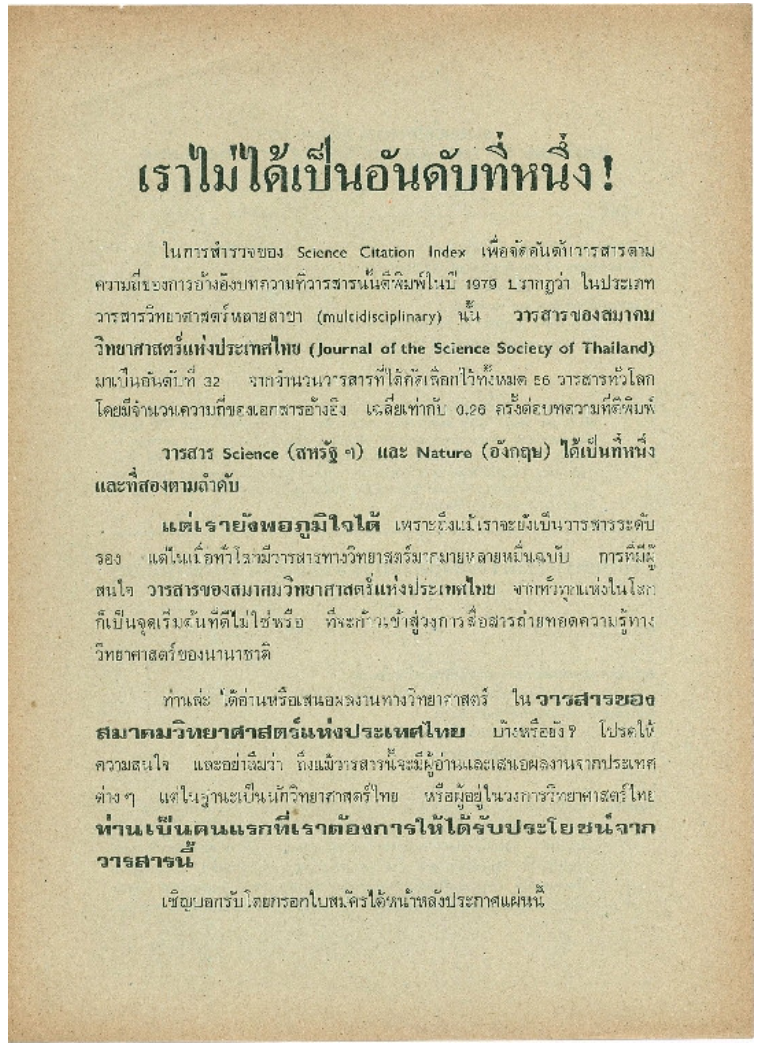

Fig. 3 The rallying cry for the journal, around 1979.

Svasti (1985-1987; 2001-2007); Yodhatai Thebtaranonth (1988-1989); Prapon Wilairat (19901991); I-Ming Tang (1992-1998) and Worachart Sirawaraporn (2008-present). As the last millennium was coming to an end, I was again asked to take the helm of editorship of the journal, which I did for two years (1999-2000). Together with people in the Society and elsewhere, we agreed that Thailand had come to an important juncture of opening even more to the outside world. We considered that Thailand is a key integral part of Asia and of the world, and decided to change the name of the journal to ScienceAsia (cover of first issue in Fig. 4), in order to reflect the widening role of Thai science in the world. The journal also went online as one of the first journals from Thailand, perhaps the first, to do so. The current editorial team has admirably made every issue since the beginning available online. If we continue to do our best for Thai science, perhaps one day our role will be even bigger and we can consider changing the name of the journal once more. ScienceWorld perhaps?

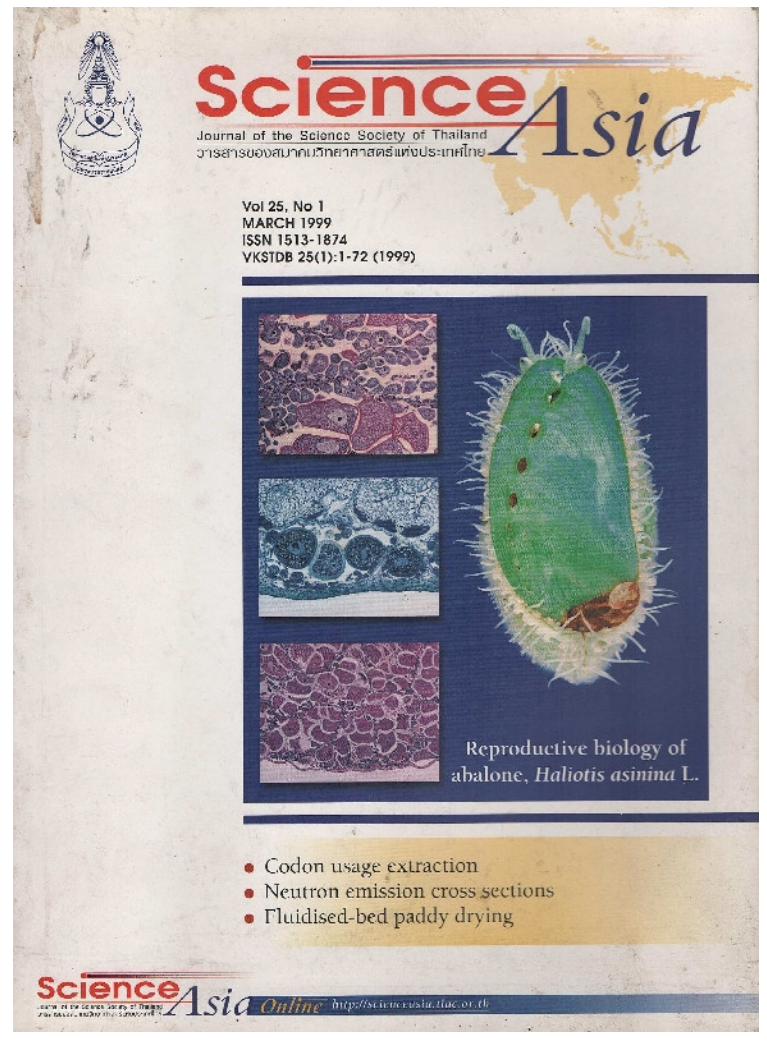

Fig. 4 The first issue of ScienceAsia (new name for the journal), 1999.

\section{REFERENCES}

1. Austin CR (1975) Preparation of the mammalian spermatozoon for fertilization. $J$ Sci Soc Thai 1, 23-9.

2. Bhathal RS (1975) Science centres. J Sci Soc Thai 1, 30-6.

3. Lehmann H, Lang A (1975) Haemoglobin Q and thalassaemia. J Sci Soc Thai 1, 41-8.

4. Svasti J, Viriyachai $S$ (1975) The purification of lactate dehydrogenase isozymes LDH- $\mathrm{A}_{4}, \mathrm{LDH}-\mathrm{B}_{4}$ and $\mathrm{LDH}-\mathrm{C}_{4}$ from human tissues. $J$ Sci Soc Thai 1, 57-71.

5. Moravcsik MJ (1975) Scientists and development. J Sci Soc Thai 1, 89-95.

6. Sabhasri S (1975) Science research policy of Thailand. J Sci Soc Thai 1, 96-102.

7. Pirie NW (1975) Methods and merits of fodder fractionation. $J$ Sci Soc Thai 1, 103-13.

8. Sangvichien S, Subhavan V (1976) Skull trephning in prehistory. J Sci Soc Thai 2, 142-7. 